DOI: $10.21554 / \mathrm{hrr} .041801$

\title{
FAMILY AS AN INDICATOR OF ACHIEVEMENT OF DEAF AND HARD OF HEARING STUDENTS
}

\section{Ivana Pavković ${ }^{1}$ \\ Ivana Roksandić \\ Jasmina Kovačević}

\author{
Life Skills Improvement Center, Belgrade \\ Elementary school "Radivoj Popović", Zemun \\ Faculty for special education and rehabilitation, University of Belgrade
}

Original scientific paper

Received: 1.10 .2017

Accepted: 25.12.2017

\begin{abstract}
The formation of an educated and a successful personality depends on a number of pedagogical, sociological and social factors. In the process of socialization and education, both contemporary school system and family share responsibility and make an important role in the success, not only of individuals, but of society as a whole. The influence of the family environment on achievement can be seen from different aspects. The aim of the research was to examine the connection between achievement of deaf and hard-of-hearing students and factors of the family environment seen through their socioeconomic status. The survey sample comprised 59 parents of deaf and hard-of-hearing children attending the school for deaf and hard-of-hearing students in the territory of the Republic of Serbia. In the process of relevant literature research and determining the theoretical facts relevant for the research problem, the method of theoretical analysis and synthesis was used. In relation to research techniques, survey and content analysis were used. Family questionnaire was used to analyze the link between the socioeconomic status of families and achievement of deaf and hard-of-hearing students. The results have shown that there was no correlation between the socioeconomic status of the families and the school achievements of deaf and hard-of-hearing students.
\end{abstract}

Keywords: factors of the family environment, deaf and hard-of-hearing students, achievement of deaf students

\section{INTRODUCTION}

The formation of an educated and a successful personality depends on a number of pedagogical, sociological and social factors. In the process of socialization and education, both contemporary school system and family share responsibility and make an important factor of success, not only of individuals, but of society as a whole.
The term of success in everyday school practice and pedagogical work is often present as a term that defines the current and ultimate achievement of students. Achievement is a subjective assessment of an activity, or a personal feeling that gives certain results. Therefore, a student who is capable of achieving certain personal goals and at the same time fulfilling his own, but also the expectations of his parents and teachers, is a successful student (Roksandić, 2016).

\footnotetext{
$\overline{{ }^{1} \text { Correspondence to: }}$

Jasmina Kovačević, University of Belgrade, Faculty of Special Education and Rehabilitation

Visokog Stevana 2, 11000 Belgrade, Serbia

Phone: +38765 2052771

E-mail: kovacjasmina@gmail.com
} 
On the one hand, the achieved success encourages devotion and forms a positive attitude towards further learning, while experiencing failure reduces the interest in further work, discourages and inhibits it.

The influence of the family environment on achievement can be seen from different aspects. The social and economic status of the family are the general aspects of the family environment. On the other hand, the active involvement of parents in the education of their children, involvement in creating work habits, assistance in doing homework, makes a psychologically-pedagogical aspect. The set of social and cultural features of the family and the personality of the parents are factors that can make the family environment stimulating for the development and achievement of school success, or, in contrast, a non-motivating one. The family environment, that can be considered as motivating and stimulating for the child's development and school success, is complex and involves a wide range of issues, such as financial situation in the family of a student, family relationships, encouraging the student and parental monitoring of schoolwork. The influence of the family environment significantly reflects on: the level and quality of achievement, development of motivation, attitudes towards the school, development of interest, personality and competences that are relevant for achievement, competence development and life success. Parents can very effectively initiate a number of activities that will create conditions for the development of their child's motivation (Trebješanin, 1986).

There is a large number of research papers that point to the socioeconomic and sociocultural stimulating aspect of the family, which differ according to the relevance level attributed to one of the groups of factors. A group of authors (Taylor et al., 1997; Leinonen et al., 2003) emphasize the influence of economic status on achievement, whereas other researchers (Redding, 2005) consider the family relationships and patterns of family behavior to be the strongest factors that determine the child's school achievement.

\section{Socioeconomic status of the family and achieve- ment of deaf and hard-of-hearing students}

The issue of the school success of deaf and hard-ofhearing students makes a particularly complex influence of different indicators in collaboration with the consequences of primary impairment. Generally speaking, the average school success of deaf and hard-of-hearing students is well below the level of their peers (Traxler, 2000). However, the average often hides a wide range of achievements, and there are deaf and hard-of-hearing students who achieve school success proportionate to their peers in a regular school (Karchmer \& Mitchell, 2003). A number of variables that positively or negatively affect school achievement have been studied by a large number of researchers (Luckner \& Muir, 2001; Mitchell \& Karchmer, 2006; Powers, 2003). The tested variables include demographic variables, which are: level of hearing impairment, ethnicity, school variables such as level and type of special support in education, and family variables, parental resources and support, and socioeconomic status.

Educational level of parents, family income and the profession of parents have been stated as the most reliable indicators of the socioeconomic status (Francis \& Munjas, 1976). Variables, such as the amount of family income, employment of parents and living conditions, were used in this research as indicators of socioeconomic status. Results of the research on the connection between family environment and achievement have shown that there is a significant correlation between father's level of education and school success, as well as the one between family income and housing conditions (Stanojlović, 2012). Among the results of research that included a family and school success comparison (Zorman, 1982), it was concluded that the level of parents' education significantly influenced the students' success. Findings of foreign research have shown the difference in academic achievement of pupils of different socio-economic status, whereas less successful students were those of lower socio-economic status of the family and students of minority groups (Desimone \& Long 2010; Haycock, 2001; Kober, 2001; Ladson-Billings, 2006; Lubienski, 2002).

\section{The aim of the research}

The aim of the research was to examine the connection between the factors of the family environment seen through its socioeconomic status and the school achievements of deaf and hard-of-hearing students.

\section{The aim of the research}

The aim of the research was to examine the connection between the factors of the family environment seen through its socioeconomic status and the school achievements of deaf and hard-of-hearing students. 


\section{The research sample}

The research sample comprised 59 parents of deaf and hard-of-hearing children attending school for the deaf and hard-of-hearing in the territory of the Republic of Serbia.

\section{Methods, techniques and instruments}

The method of theoretical analysis and synthesis was used in relevant literature research, as well as in determining significant theoretical facts. Survey and content analysis were used in relation to research techniques. In addition to general information about the respondent, the questionnaire for parents included a list of questions related to the living conditions and student's work, the behavior of the child, the family involvement in school activities and homework assignments.

\section{RESULTS OF RESEARCH AND DISCUSSION}

\section{Education of parents, family income and achieve- ment of deaf and hard-of-hearing students}

Numerous worldwide studies have shown the connection between the socioeconomic status of the family and achievement (Sirin, 2005). In their research, the authors stated that parents with higher education, which is one of the preconditions of the stimulating family atmosphere, cooperate with teachers more intensively by helping children to overcome difficulties and are more interested in the child's success (Fantuzzo et al., 2000). In such families, children are more motivated and more ambitious for schoolwork and engagement in school and outdoor activities. It is stated that parents' education can be a potential factor in achievement of their children by activating its incentive capacities with personal, intellectual and active involvement in creating and providing direct conditions for the development of a child (Grolnick \& Slowiaczek, 1994; Grolnick et al., 1997). The results of the research that relate to the socioeconomic status of a family, according to the parameters of father's education, have shown that the arithmetic mean of school achievements $\mathrm{M}=4.38$, was the highest among those students whose fathers were highly educated, while the lowest arithmetic mean $\mathrm{M}$ $=3.91$, resulted among pupils whose fathers had no primary education (Table 1). Also, the results related to the educational level of mother have shown that the arithmetic mean of achievement $\mathrm{M}=4.38$ was the highest among students whose mothers were highly educated, while average achievements were recorded among the students whose mothers had university education - degree VI $(\mathrm{M}=4.17)$ or primary education $(\mathrm{M}=4.12)$. The arithmetic mean of achievement of students whose mothers had secondary education was $\mathrm{M}=3.97$, while students whose mothers had no education had the lowest average school achievement (Table 2).

In relation to achievement and financial status, the results of this study showed that averagely the lowest personal income is provided for families of the best students; in the second place are the families of the less successful students, while the students with the lowest achievement have the highest financial status (Table 3). The results of the study showed that there is a very high $(\mathrm{r}=.802)$ statistically significant correlation between the educational level of father and mother, as well as the personal income is in a high, significant correlation with the education of both parents. There is, however, no connection between the socioeconomic status of the family shown through the educational and financial status and achievement of the students (Table 4). Such findings are contrary to the results of studies that indicate the education of the mother as a strong predictor of educational outcomes and achievements (Stevenson \& Baker, 1987). Also, the results are contrary to the findings of the research which, as the causative factors of the failure of the deaf and hard of hearing, indicate a low socioeconomic status, degree of hearing impairment, and the presence of other cognitive and behavioral problems (Karchmer \& Mitchell, 2003). The results of this research can be explained by the fact that parents of deaf and hard of hearing children, of higher educational level and better financial status, are unable to encourage child progress due to lack of time, lack of motivation, unwillingness to engage in the educational process of their child, leaving it completely to experts and special education teachers. Furthermore, greater involvement of parents through different forms of participation in the education of children also requires greater competence of parents. In addition to this, foreign studies have shown there is a correlation of knowledge, skills and competences of parents and achievement of deaf and hard-of-hearing students (Bodner-Johnson, 1986, Kluwin \& Gaustad, 1992). 
Table 1. Achievement in relation to educational level of father

\begin{tabular}{lccc}
\hline $\begin{array}{l}\text { Incomplete primary education } \\
\text { Average }\end{array}$ & $\mathbf{N}$ & $\mathbf{M}$ & Sd \\
\hline $\begin{array}{l}\text { Primary education } \\
\text { Average }\end{array}$ & 2 & 3.91 & 1.29 \\
\hline $\begin{array}{l}\text { Secondary education } \\
\text { Average }\end{array}$ & 10 & 4.12 & .90 \\
\hline $\begin{array}{l}\text { University education (degree VI) } \\
\text { Average }\end{array}$ & 35 & 3.97 & .92 \\
$\begin{array}{l}\text { University education(degree VII) } \\
\text { Average }\end{array}$ & 2 & 4.17 & 1.16 \\
\hline
\end{tabular}

Table 2. Achievement in relation to educational level of mother

\begin{tabular}{lccc}
\hline $\begin{array}{l}\text { Incomplete primary education } \\
\text { Average }\end{array}$ & $\mathbf{N}$ & M & Sd \\
\hline $\begin{array}{l}\text { Primary education } \\
\text { Average }\end{array}$ & 3 & 3.27 & 1.43 \\
\hline $\begin{array}{l}\text { Secondary education } \\
\text { Average }\end{array}$ & 14 & 3.84 & 1.06 \\
$\begin{array}{l}\text { University education (degree VI) } \\
\text { Average }\end{array}$ & 31 & 4.17 & .89 \\
\hline $\begin{array}{l}\text { University education (degree VII) } \\
\text { Average }\end{array}$ & 2 & 2.93 & .09 \\
\hline
\end{tabular}

Table 3. Achievement of the students in relation to financial status of the family

\begin{tabular}{llccc}
\hline School success & & N & M & Sd \\
\hline Sufficient & Personal income & 4 & 16250.00 & 16700.80 \\
\hline Good & Personal income & 8 & 3856.88 & 3152.15 \\
\hline Very good & Personal income & 8 & 10500.00 & 10690.45 \\
\hline
\end{tabular}

Table 4. Spearman's correlation coefficient between the students'achievements, parents' education and financial status of the family

\begin{tabular}{lccc}
\hline & Education of father & Education of mother & Personal income \\
\hline School achievements & .026 & .044 & -.030 \\
\hline Education of father & $.802^{* *}$ & $.524^{* *}$ \\
\hline Education of mother & & $.502^{* *}$ \\
\hline${ }^{* *}$ - Correlation is significant at the level .01 & & \\
${ }^{*}$ - Correlation is significant at the level .05 & & \\
\hline
\end{tabular}

Parents' employment, living conditions and in our country for the past two decades, there is no posachievement of deaf and hard-of-hearing students sibility of finding a job according to the degree of vocational education, which makes a noticeable gap be-

Due to the poor economic situation and political events tween the educational degree and the job of a person. 
Because of that, the educational degree of parents was not considered in this study as a potential factor that can contribute to school success or failure. However, the employment of parents was highly correlated with the quality of life, and the intention was to determine whether the parents of the students from our sample were employed, as well as to determine the potential connection between the employment of the parents and the achievement of students. The analysis of the variance examined indicated whether the employment of parents (Table 5) and living conditions (Table 6) were factors in the achievement of deaf and hard-of-hearing students. The results showed that no statistically significant differences were identified in the achievement of students from families of different socio-economic status seen in relation to the employment of parents and living conditions. The results of the similar study showed that, in the situation where both parents were employed, but in regard to father's employment, no significant differences were identi- fied between the students who failed and repeated the year and those who passed the year, while in the situation of mother's employment, the differences between student groups were statistically significant (Malinić, 2009). However, the results obtained are incompatible with the results of the research that showed a high correlation between school success or failure and controlling the student's homework (Troy, 1967). The findings of this research could be explained by the existence of well-organized pedagogical work in schools for deaf and hard-of-hearing students, in which students receive adequate forms of support to achieve the results. They also get support from their teachers to finish the lessons and assignments at school.

Considering the results of this research that relate to the stated aspects of socioeconomic status, the educational level of parents, financial status, employment and living conditions of the family, it is concluded that it does not make a factor of the achievement of deaf and hard-of-hearing students.

Table 5. Significance of differences between respondents from families of employed or unemployed parents in relation to achievement

\begin{tabular}{|c|c|c|c|c|c|}
\hline Employment of parents & $\mathbf{N}$ & $\mathbf{M}$ & Sd & $\mathbf{F}$ & $\mathbf{p}$ \\
\hline Both parents employed & 14 & 4.14 & .95 & \multirow{3}{*}{1.68} & \multirow{3}{*}{0.197} \\
\hline One parent employed & 22 & 4.23 & .88 & & \\
\hline Both parents unemployed & 17 & 3.70 & .97 & & \\
\hline
\end{tabular}

Table 6. Significance of differences between respondents from families of different housing status in relation to achievement

\begin{tabular}{lccccr}
\hline Housing status & N & M & Sd & F & t \\
\cline { 1 - 4 } Subtenants & 11 & 3.94 & .97 & & \\
\cline { 1 - 3 } One-room or two bedroom apartment & 24 & 3.89 & .96 & .818 \\
\cline { 1 - 3 } Three bedroom apartment & 22 & 4.07 & .97 & & \\
\hline
\end{tabular}

\section{CONCLUSION}

The influence of the socioeconomic status of the family on student's achievement is the subject to numerous studies. Different variables and factors were included in the research models, countries and schools were compared; the family, the school, financial and social status of the family were correlated. The levels of influence of socioeconomic status on student achievements were examined, and in each new study some variables were added and some were excluded from the model in order to obtain the most relevant data. Most of the authors confirmed the correlation between the socio- economic status and achievement (Gregurović, 2010). On the other hand, some studies showed that the social environment in an early childhood as well as the intellectual stimulation of children are more important than the socioeconomic status of their parents (Zloković, 1998). The results of this research showed that the socioeconomic status of the family is not a factor in achievements of deaf and hard-of-hearing students. The results of this study could be explained by the fact that parents of deaf and hard of hearing children, despite the university level, were not able to encourage child progress due to communication barriers, lack of time, motivation or competence. 


\section{REFERENCES}

Bodner-Johnson, B. (1986). The family environment and achievement of deaf students: A discriminant analysis. Exceptional Children, 52 (5), 443-449.

Desimone, L., \& Long, D. A. (2010). Teacher effects and the achievement gap: Do teacher and teaching quality influence the achievement gap between black and white and high- and low-SES students in the early grades? Teachers College Record, 112(12), 3024-3073.

Fantuzzo, J., E. Tighe \& S. Childs (2000). Family involvement questionnaire: a multivariate assessment of family participation in early childhood education, Journal of Educational Psychology,92(2), 367-376.

Flores, A. (2007). Examining disparities in mathematics education: Achievement gap or opportunity gap? The High School Journal, 91(1), 29-42.

Fancis, G. M. \& B. A. Munjas (1976). Manual of social psichologic assessment. New York. Appleton-Century-Crofts.

Gregurović, M., Kuti, S. (2010) Uticaj socioekonomskog statusa na obrazovna postignuća učenika: Primer istraživanja PISA, Hrvatska 2006. U: Žurnal o socijalnoj politici 17 (2), str.

Grolnick, W.S. \& M. L. Slowiaczek (1994). Parents' involvement in children's schooling: a multidimensional conceptualization and motivational model, Child Development, 65, 237-252.

Grolnick, W.S., C. Benjet, C.O. Kurowski \& N.H. Apostoleris (1997). Predictors of parent involvement in children's schooling, Journal of Educational Psychology, Vol. 89, No. 3, 538-548.

Haycock, K. (2001). Closing the achievement gap. Educational leadership, 58(6), 6-11.

Kluwin, T. N., \& Gaustad, M. G. (1992). How family factors influence school achievement. In: T. N. Kluwin, D. F. Moores, \& M. G. Gaustad (Eds.), Toward effective public school programs for deaf students. New York: Teachers College Press.

Kober, N. (2001). It takes more than testing: Closing the achievement gap. Washington, DC: Center on Education Policy.

Karchmer M, Mitchell RE (2003). Demographic and achievement characteristics of deaf and hard-of-hearing students: in Oxford handbook of deaf studies, language and education, eds

Ladson-Billings, G. (2006). From the achievement gap to the education debt: Understanding achievement in US schools. Educational Researcher, 35(7), 3-12

Leinonen, J., T. Solantaus \& R. P. Punamaki (2003). Social support and the quality of parenting under economic pressure and workload in Finland: the role of family structure and parental gender, Journal of Family Psychology, 17(3), 419-418.

Lubienski, S. T. (2002). A closer look at black-white mathematics gaps: Intersections of race and SES in NAEP achievement and instructional practices data. Journal of Negro Education, 71(4), 269-287.
Luckner J. L, Muir S.(2001). Successful students who are Deaf in general education settings. American Annals of the Deaf, 146:435-445.

Malinić, D. (2009). Neuspeh u školskoj klupi. Beograd: Institut za pedagoška istraživanja.

Mitchell R. E, Karchmer M. A(2006). Demographics of deaf education: More students in more places. American Annals of the Deaf, 151:95-104.

Powers, S.(2003). Influences of Student and Family Factors on Academic Outcomes of Mainstream Secondary School Deaf Students. Oxford Journals. Jnl. of Deaf Studies and Deaf Education Volume 8, Issue 1 Pp. 57-78

Roksandić, I., Kovačević, J. (2016). Saradnja porodice i škole u prevenciji školskog neuspeha učenika gluvih i teškoća. Specifičnost oštećenja sluha - novi koraci. Fakultet za specijalnu edukaciju i rehabilitaciju. Beograd, 177-195.

Roksandić I. (2016). Indikatori školskih postignuća gluvih $i$ najslušanijih učenika osnovnog školskog uzrasta. Doktorska disertacija. Fakultet za specijalnu edukaciju i rehabilitaciju. Univerzitet u Beogradu.

Roksandić I., Kovačević J. (2016). Ponašanje gluvih i teških učenika u školi $i$ školskim dostignućima. Pedagogija. Beograd.

Redding, S. (2005). Parents and learning. International Academy of Education. www.ibe.unesco.org

Sirin, S. R. (2005). Socioeconomic status and academic achievement: A metaanalytic review of research. Review of Educational Research, 75 (3), 417-453.

Stanojlović, B. (2012). Osnovi pedagoške dijagnostike. Beograd. Prosvetni pregled.

Stevenson, D.L.\& D.P. Baker (1987). The family-school relation and the child's school performance, Child Development, 58(5), 1348-1357

Taylor, R., D. Roberts \& L. Jacobson (1997). Stressful life events, psychological wellbeing, and parenting in African American mothers, Journal of Family Psychology, 11(4), 436-446.

Trebješanin, B. (1986). Internal motivation: the concept and its pedagogical-psychological implications in higher education (master's thesis). Belgrade: Faculty of Philosophy, 21, 68-91.

Troj, F. (1967). Učešće nekih faktora u lošem uspehu učenika. Zbornik instituta za pedagoška istraživanja. Bijeli grad.

Traxler CB (2000). The Stanford Achievement Test, 9th Edition: National norming and performance standards for deaf and hard-of-hearing students. Journal of Deaf Studies and Deaf Education 5(4):337-339.

Zloković, J. (1998). Nedostatsk škole - problem studenata, roditelja i nastavnika. Rijeka. Filozofski fakultet u Rijeci. Odsjek za pedagogiju.

Zorman, L. (1982). Uticaj socio-ekonomskog statusa učeničke porodice na školski uspeh $i$ nastavak obrazovanja; u Kovač-Cerović, T. (urednik). Istraživanje u pedagoškoj psihologiji. Beograd: Društvo psihologa Srbije. 